\title{
Pendampingan Masyarakat Dalam Pengolahan Sampah Organik Rumah Tangga Untuk Mendukung Program Urban Farming
}

\author{
${ }^{1}$ Reni Amaranti, ${ }^{2}$ Eri Achiraeniwati, ${ }^{3}$ Nurrahman As'ad, ${ }^{4}$ Aswardi Nasution, \\ ${ }^{5}$ M. Satori
1,2,3,4,5 Jurusan Teknik Industri Universitas Islam Bandung, Jl. Tamansari No. 1 Bandung 40116
e-mail: ${ }^{1}$ reniamaranti2709@yahoo.com, ${ }^{2}$ eri_ach@yahoo.co.id, ${ }^{3}$ nur_asad@yahoo.co.id, ${ }^{4}$ aswardinasution@yahoo.com, ${ }^{5}$ mohamad_satori@yahoo.com

\begin{abstract}
Abstrak. Komposisi sampah yang didominasi oleh sampah organik akan menjadi masalah besar apabila tidak ditangani dengan baik, tidak hanya dalam pengelolaan sampah yang ada akan tetapi juga pengurangan sampah yang dibuang ke pengolahan sampah akhir terutama berkaitan dengan masalah pencemaran lingkungan akibat penumpukan sampah. Di sinilah dibutuhkan solusi pemecahan yang mengarah pada pemanfatan teknologi sebagai upaya untuk menciptakan keadaan lingkungan yang sehat, bersih, dan bisa memberikan keuntungan dari sisi ekonomis. Dari sudut pandang lain, sebenarnya sampah rumah tangga apabila dikelola dengan baik, memiliki potensi ekonomis karena dapat dimanfaatkan untuk dijadikan kompos. Pengelolaan sampah ini bisa dilakukan pada skala ekonomis dalam area pengelolaan tingkat Rukun Tetangga (RT) maupun skala komunal setingkat lingkungan Rukun Warga $(R W)$, bahkan bisa diperluas hingga tingkat pedusunan/kelurahan. Masalah utama yang yang dihadapi mitra saat ini adalah belum meratanya pengetahuan dan kemampuan masyarakat dalam memanfaatkan sampah yang selama ini mereka hasilkan (terutama sampah organic) menjadi sesuatu yang bermanfaat dan dapat menciptakan nilai tambah bagi keluarga. Selain itu juga kurangnya sosialisasi dan arahan kepada masyarakat menyebabkan rendahnya tingkat partisipasi masyarakat terhadap program yang dilaksanakan pemerintah terutama program Kampung Berkebun yang telah dilaksanakan di tingkat Rukun Warga (RW). Untuk itu, perlu dilakukan upaya pendampingan masyarakat dalam mengelola sampah terutama sampah organik rumah tangga dan memanfaatkannya untuk mendukung kegiatan urban farming. Kegiatan ini dilakukan dengan tujuan (a) meningkatkan pengetahuan masyarakat mengenai cara pengolahan sampah organik rumah tangga, (b) meningkatkan kemampuan masyarakat dalam mengolah sampah organik rumah tangga menjadi kompos dengan beberapa teknik pembuatan kompos, (c) meningkatkan kemampuan masyarakat dalam urban farming (pertanian urban) sehingga dapat merespon dengan baik program pemerintah yang telah ada selama ini (program kampung berkebun), serta (d) mengoptimalkan potensi yang ada di masyarakat mitra menjadi kegiatan produktif dan bernilai ekonomis.
\end{abstract}

Kata Kunci : pengolahan sampah, sampah organik, urban farmings

\section{Pendahuluan}

Kota Bandung merupakan Ibu Kota Provinsi Jawa Barat, memiliki pertumbuhan yang cukup pesat dipicu oleh proses perdagangan, pariwisata, pendidikan dan pemukiman. Pertumbuhan ekonomi Kota Bandung ini berdampak positif maupun negatif, dan yang paling dirasakan adalah semakin berkurangnya lahan produktif pertanian untuk pengembangan budidaya pertanian. Pertumbuhan penduduk yang tinggi menyebabkan tuntutan akan pemenuhan penyediaan pangan yang meningkat untuk tingkat rumah tangga dan menurunnya kualitas lingkungan hidup. Masalah sampah juga menjadi 
masalah yang krusial di Kota Bandung. Timbulan sampah yang terus meningkat dari tahun ke tahun seiring dengan pertumbuhan penduduk dan gaya hidup masyarakat, namun di sisi lain kapasitas pelayanan yang makin terbatas baik karena sulitnya mencari lahan TPA (tempat pemrosesan akhir) maupun karena keterbatasan armada angkut merupakan permasalahan yang harus dihadapi Kota Bandung.

Saat ini, komposisi sampah Kota Bandung (dalam \% berat) didominasi oleh sampah organik dan sisa makanan yang mudah busuk. Data dari website Kota Bandung disebutkan bahwa komposisi sampah Kota Bandung adalah 42\% organik, 27\% sisa makanan, 9\% plastik, 5\% tekstil, 3\% karet, dan 14\% lain-lain. Komposisi sampah seperti ini akan menjadi masalah besar apabila tidak ditangani dengan baik, tidak hanya dalam pengelolaan sampah yang ada akan tetapi juga pengurangan sampah yang dibuang ke pengolahan sampah akhir terutama berkaitan dengan masalah pencemaran lingkungan akibat penumpukan sampah. Apabila penanganan sampah tidak segera mendapatkan penanganan dari berbagai pihak, dan hanya mengandalkan dari upaya pemerintah daerah setempat, niscaya akan berdampak semakin memburuknya keadaan lingkungan di sekitarnya, jauh dari terciptanya kelestarian lingkungan hidup yang sehat dan bersih. Di sinilah dibutuhkan solusi pemecahan yang tepat untuk menciptakan keadaan lingkungan yang sehat, bersih dan sekaligus bisa memberikan keuntungan dari sisi ekonomis. Dari sudut pandang lain sebenarnya sampah rumah tangga tidak selalu menjadi sumber masalah apabila dikelola dengan baik. Jumlah sampah yang dihasilkan dari rumah tangga yang semakin besar dapat menjadi sumber ekonomi dan pendapatan bagi masyarakat setempat. Sampah organik limbah rumah tangga memiliki potensi ekonomis karena dapat dikelola dengan mudah untuk dijadikan kompos dengan memanfaatkan teknologi tepat guna komposter. Pengelolaan sampah ini bisa dilakukan pada skala ekonomis dalam area pengelolaan tingkat Rukun Tetangga (RT) maupun skala komunal setingkat lingkungan Rukun Warga (RW), bahkan bisa diperluas hingga tingkat pedusunan/kelurahan.

Mengenai kegiatan Urban Farming, Pemerintah Kota Bandung telah menggulirkan Program Kampung Berkebun dengan tujuan untuk pemenuhan kebutuhan pangan segar bagi masyarakat dan untuk perbaikan kualitas lingkungan pemukiman menjadi hijau, nyaman, asri, bersih, dan produktif (Kusnadi, 2014). Warga RW 11 Kelurahan Cipadung Kidul merupakan salah satu RW yang menjadi wilayah binaan pemerintah Kota Bandung untuk program Kampung Berkebun tersebut. Dampaknya, sebagian warga telah melakukan kegiatan berkebun di lingkungan masing-masing dengan memanfaatkan lahan yang dimiliki. Akan tetapi, tidak semua RT di RW 11 telah merespon Program ini dengan baik, salah satu nya adalah RT 01. Sosialisasi yang kurang memadai dan tidak adanya pengetahuan mengenai bagaimana program tersebut dilaksanakan membuat dampak program menjadi tidak menyeluruh dan merata pada semua RT yang ada di wilayah RW 11. Program Kampung Berkebun ini juga belum diselaraskan dengan pemanfaatan sampah organik yang dihasilkan rumah tangga menjadi pupuk kompos. Untuk itu perlu dilakukan kegiatan peningkatan pengetahuan dan kemampuan masyarakat mengenai bagaimana mengolah sampah organik rumah tangga menjadi sesuatu yang bermanfaat diselaraskan dengan kegiatan urban farming (program Kampung Berkebun) yang telah ada di tingkat RW. Dengan demikian semua potensi yang telah ada di masyarakat dapat dimanfaatkan secara optimal dan dampak yang dirasakan masyarakat dari program yang telah dilaksanakan oleh pemerintah dapat menyeluruh, merata, dan berkelanjutan. 


\section{Metode Pelaksanaan}

Berdasarkan analisis pada potensi, sumber daya yang dimiliki, permasalahan utama yang terjadi serta target luaran, maka solusi yang ditawarkan adalah memberikan pelatihan tentang pengolahan sampah rumah tangga dan pelatihan berkebun (skala kecil dan sederhana) terhadap masyarakat mitra serta melakukan pendampingan untuk mempraktekkan hasil pelatihan. Solusi tersebut diharapkan dapat meningkatkan keterampilan warga dalam mengolah sampah rumah tangga dan memanfaatkannya untuk kegiatan berkebun di sekitar rumah sehingga dapat menghasilkan bahan pangan untuk konsumsi rumah tangga dan akhirnya memberikan dampak besar pada perekonomian keluarga. Adapun kegiatan atau langkah-langkah yang akan dilakukan dalam pendampingan pengolahan sampah organik rumah tangga untuk mendukung program urban farming tersebut adalah sebagai berikut :

1. Studi pendahuluan dan sosialisasi, mencakup identifikasi lebih lengkap mengenai kondisi sosio ekonomi masyarakat mitra serta melakukan sosialisasi pelaksanaan program pengabdian masyarakat yang akan dilakukan di lokasi mitra. Pada tahap ini juga akan diidentifikasi siapa saja yang akan menjadi koordinator dalam pelaksanaan program ini.

2. Menyusun rencana serta jadwal pelaksanaan kegiatan berdasarkan kesepakatan dengan koordinator lapangan dan pengurus RT sehingga diharapkan seluruh kegiatan yang diusulkan dapat terlaksana dengan baik sesuai dengan tujuan yang ingin dicapai dan waktu yang ditentukan.

3. Identifikasi karakteristik dan timbulan sampah yang ada di lingkungan masyarakat mitra. Karakteristik dan timbulan sampah akan menjadi masukan untuk menentukan metode pengolahan sampah yang akan dilakukan serta memperkirakan alat yang akan digunakan dalam mengolah sampah tersebut.

4. Identifikasi materi dan metode pelatihan yang akan diberikan dengan mengidentifikasi terlebih dahulu pengetahuan awal masyarakat mitra dalam masalah pengolahan sampah organik dan urban farming dan informasi detail mengenai pelatihan apa saja yang telah diperoleh oleh masyarakat mitra. Pada tahap ini juga ditentukan metode pelatihan yang dinilai tepat untuk masyarakat mitra.

5. Melaksanakan Pelatihan, yaitu pelatihan bagaimana memilah sampah dengan benar, pelatihan mengenai pengolahan sampah organik menjadi kompos, serta pelatihan bercocok tanam dengan memnafaatkan lahan di sekitar rumah.

6. Melakukan Pendampingan, meliputi memberikan bantuan dan bimbingan pada proses penyiapan peralatan dan tempat, melakukan praktek pembuatan kompos sesuai dengan metode yang disepakati dan dinilai tepat untuk masyarakat mitra, serta mendampingi masyarakat untuk praktek berkebun dengan memanfaatkan lahan serta peralatan yang dimiliki masing-masing rumah tangga di lingkungan masyarakat mitra.

7. Monitoring dan Evaluasi program, terutama evaluasi mengenai kendalakendala yang dihadapi serta upaya untuk menyelesaikannya termasuk juga mengidentifikasi peluang-peluang untuk perluasan kegiatan yang lainnya seperti ke pengolahan sampah anorganik atau potensi pembentukan Bank Sampah. Evaluasi dilakukan secara bertahap, yaitu : 
- Evaluasi tahap pertama yaitu evaluasi yang dilakukan untuk mengetahui peningkatan pengetahuan masyarakat mengenai pengelolaan sampah organik rumah tangga.

- Evaluasi tahap kedua yaitu evaluasi yang dilakukan untuk mengetahui peningkatan kemampuan masyarakat dalam mengimplementasikan hasil pelatihan yang telah mereka terima serta mengetahui partisipasi masyarakat dalam kegiatan PKM yang diusulkan.

- Evaluasi tahap ketiga yaitu evaluasi yang dilakukan untuk mengetahui tingkat keberhasilan pelaksanaan PKM secara keseluruhan. Evaluasi ini dilakukan pada periode terakhir masa PKM bersamaan dengan pembuatan laporan akhir pelaksanaan PKM.

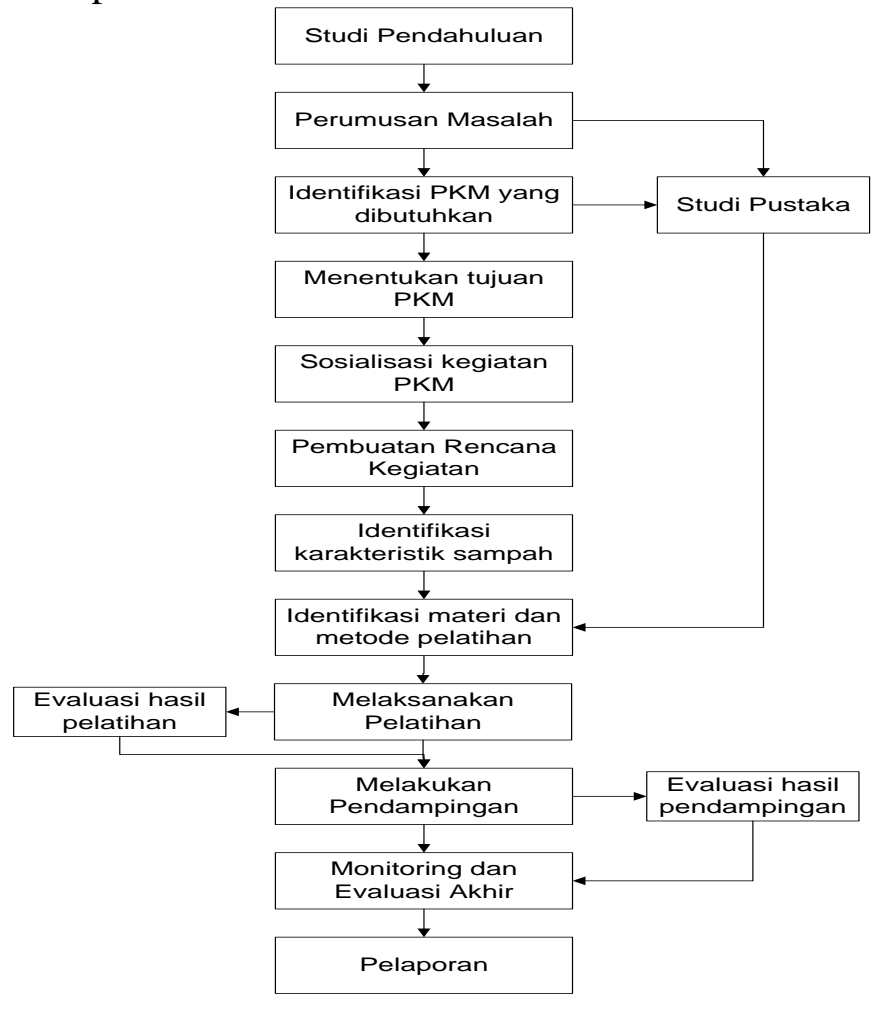

Gambar 1. Tahapan Pelaksanaan PKM

\section{Hasil yang Dicapai}

\subsection{Studi Pendahuluan dan sosialisasi}

Studi pendahuluan dilakukan untuk mengetahui dengan lebih lengkap mengenai kondisi mitra PKM. Hasil pengamatan atau studi menunjukkan bahwa :

- Pengelolaan sampah organik yang biasa dilakukan masyarakat adalah dengan membuang sampah rumah tangga secara tercampur ke tempat sampah yang tersedia di setiap rumah. Saat ini belum ada kegiatan pemilahan sampah di rumah tangga sebelum dibuang ke tempat sampah masing-masing. Akan tetapi, ada beberapa rumah tangga yang telah memanfaatkan sebagian sampah organik yang mereka hasilkan untuk menyuburkan tanaman walaupun caranya masih sangat sederhana. Pemanfaatan sampah organik untuk pupuk hanya dengan 
menyimpan sampah tersebut di pot-pot tanaman dan membiarkannya membusuk.

- Jenis sampah yang ada didominasi oleh sampah organik seperti sisa sayuran, sisa nasi, sisa lauk (sisa sayur, sisa ikan, sisa daging), selebihnya sampah non organik (kantong kresek, kantong kemasan makanan, botol minuman plastik, dan kertas).

- Sampah yang dibuang ke tempat sampah biasanya telah dibungkus dengan kantong kresek.

- Pengetahuan masyarakat mengenai cara pengelolaan sampah organik rumah tangga masih terbatas.

Sosialisasi kegiatan PKM dilakukan melalui tokoh masyarakat dan melalui pengurus RT. Tim melakukan pertemuan dengan pengurus RT dan pengurus PKK untuk memberitahukan pelaksanaan PKM. Saat sosialisasi disampaikan mengenai tujuan pelaksanaan PKM dan rencana kegiatan yang akan dilakukan.

\subsection{Penyusunan rencana Pelaksanaan PKM}

Beberapa hal yang menjadi pertimbangan dalam menyusun rencana, diantaranya adalah kegiatan-kegiatan RT atau di tingkat RW yang kemungkinan sama dengan kegiatan PKM yang dilakukan. Hasil kegiatan tahap ini adalah jadwal pelaksanaan PKM.

\subsection{Pelaksanaan pelatihan}

Untuk meningkatkan pengetahuan masyarakat mitra maka dilakukan pelatihan mengenai pengelolaan sampah organik rumah tangga dengan materi mengenai pemanfaatan sampah organik rumah tangga, pembuatan kompos dengan metode Takakura, serta berkebun di pekarangan rumah. Pelatihan dengan materi mengenai berkebun, tim pelaksana PKM bekerjasama dengan Dinas Pertanian dan Ketahanan Pangan Kota Bandung. Materi yang disampaikan pada kegiatan pelatihan yang dilakukan adalah :

- Pengelolaan Sampah Berbasis Masyarakat dengan Pola 3R, disampaikan oleh M. Satori, Ir., M.T.

- Pembuatan Kompos dengan Metode Takakura, disampaikan oleh M. Satori, Ir., M.T. dan Reni Amaranti, S.T., M.T.

- Budidaya tanaman di lahan pekarangan melalui gerakan bandung berkebun, disampaikan oleh petugas dari Dinas Pertanian dan ketahanan pangan Kota Bandung.

Pelatihan dilakukan selama 1 hari dengan peserta ibu-ibu PKK RT 01, beberapa orang bapak-bapak warga RT 01, serta perwakilan PKK RW. Pada kegiatan pelatihan ini juga dilakukan pembagian Komposter Takakura, bibit tanaman, polybag, serta media tanam.

Setelah pelatihan, dilakukan evaluasi untuk mengetahui peningkatan pengetahuan masyarakat mengenai pengelolaan sampah organik rumah tangga menjadi produk yang bermanfaat. 


\subsection{Pendampingan}

Hasil pendampingan menunjukkan tingkat pemanfaatan fasilitas yang telah dibagikan (komposter Takakura) belum optimal. Beberapa hal yang menjadi kendala adalah kualitas inokulan dalam Komposter Takakura kurang bagus sehingga proses pengomposan tidak optimal, serta tanaman diserang hama tanaman sehingga hasil berkebun tidak maksimal. Pendampingan juga membantu masyarakat untuk tidak menyerah apabila mengalami kegagalan dalam berkebun maupun dalam mengolah sampah organik.

\subsection{Monitoring dan evaluasi}

Hasil kegiatan evaluasi dan monitoring yang dilakukan :

- Sebagian besar masyarakat mitra telah memilah sampah sebelum dibuang, akan tetapi pemilahan dan perlakuan yang dilakukan untuk sampah yang dipilah tersebut berbeda-beda.

- Rumah tangga yang belum memilah sampah saat membuang sampah sebagian besar tidak mengikuti pelatihan yang dilakukan.

- Sekitar 25\% dari masyarakat mitra yang mendapat pembagian alat komposter takakura, telah mengolah sampah dan memanfaatkan alat tersebut dengan baik. Sebagian yang lain belum menggunakan dan memanfaatkannya untuk mengolah sampah organik rumah tangga. Pengolahan sampah organik yang dilakukan saat ini adalah membuang langsung ke dalam pot-pot tanaman atau membuang secara terpisah dengan sampah kering atau anorganik.

- Perlakuan terhadap sampah kering atau sampah anorganik sebagian besar masih dibuang langsung dalam tempat terpisah atau diberikan kepada pemulung atau tukang rongsokan yang sering mengambil sampah di lingkungan masyarakat mitra.

- Untuk kegiatan berkebun, sekitar 30\% masyarakat mitra telah melakukan kegiatan berkebun di halaman rumah masing-masing dengan berbagai cara dan media. Secara umum kegiatan berkebun yang dilakukan masih bersifat seadanya dan tidak ditangani dengan sungguh-sungguh.

- Untuk kegiatan berkebun, sebagian besar masyarakat mengeluhkan kurangnya pengetahuan mereka dalam merawat tanaman dan menangani hama tanaman sehingga hasil panen tanaman tidak memuaskan atau bahkan tanaman mati.

Hasil evaluasi secara umum menunjukkan bahwa kegiatan yang dilakukan telah mengubah perilaku masyarakat mitra dalam membuang sampah (memilah sampah sebelum dibuang), akan tetapi belum memberikan dampak yang signifikan terhadap pemanfaatan sampah organik pada kegiatan urban farming (hanya memberikan peningkatan sekitar 25-30\%). Walaupun demikian pendekatan dan pendampingan terus dilakukan oleh tim sehingga diharapkan dampak yang diberikan akan semakin besar. Beberapa hal yang dianggap perlu dilakukan dan diusulkan juga oleh masyarakat mitra untuk dilakukan adalah :

- Membuat satu tempat khusus utnuk melakukan kegiatan berkebun dan juga untuk mengolah sampah organik.

- Membuat kegiatan untuk mengolah sampah kering atau anorganik yang selama ini telah mereka pilah atau membuat kegiatan yang dapat membuat sampah 
anorganik menjadi uang. Tim PKM menerjemahkan usulan masyarakat ini menjadi kegiatan inisiasi pembentukan bank sampah.

- Membuat kegiatan pelatihan dan pendampingan lanjutan mengenai cara bercocok tanam atau berkebun termasuk berkebun dengan metode hidroponik.

- Melakukan kegiatan berkebun secara lebih besar lagi termasuk penataan lingkungan masyarakat mitra agar lebih memungkinkan untuk melakukan kegiatan berkebun dengan lebih baik.

\section{Kesimpulan dan Saran}

Pendampingan masyarakat dalam mengelola sampah organik rumah tangga merupakan kegiatan yang memerlukan kecermatan membaca situasi dan menentukan strategi pelaksanan kegiatan yang tepat sehingga tujuan dapat dicapai secara optimal. Beberapa kendala yang dihadapi tidak semestinya menghalangi proses. Kendalakendala yang dihadapi diantaranya adalah tingkat partisipasi warga mitra dalam kegiatan pelatihan dikarenakan berbagai alasan. Hal ini akan berdampak pada pencapaian tujuan PKM. Pembuatan rencana pelaksanaan kegiatan PKM yang akurat dapat meminimasi bias dalam pelaksanaan PKM ini.

Hasil evaluasi menunjukkan bahwa kegiatan yang dilakukan telah mengubah perilaku masyarakat mitra dalam membuang sampah (memilah sampah sebelum dibuang), akan tetapi belum memberikan dampak yang signifikan terhadap pemanfaatan sampah organik pada kegiatan urban farming. Selanjutnya disarankan untuk mengubah pola monitoring dan evaluasi yang dilakukan sehingga warga menjadi nyaman dan tidak merasa digurui dan sedang dinilai.

\section{Daftar pustaka}

Anik Krismawati dan Rika Asnita, 2011, Pupuk Organik dari Limbah Organik Rumah Tangga, SinarTani-Agroinovasi, Badan Litbang Pertanian Jawa Timur, Edisi 3-9 Agustus 2011 Nomor 3417 Tahun XLI

Daniel Hoornweg dan Paul Munro-Faure, 2008, Urban Agriculture For Sustainable Poverty Allevation and Food Security. www.fao.org/fileadmin/templates/FCIT/PDF/UPA_WBpaper_final_Oktober_2008.pdf Faizah, 2008, Pengelolaan Sampah Rumah Tangga Berbasis Masyarakat (Studi Kasus di

Kota Yogyakarta), Tesis, Program Magister Ilmu Lingkungan Program Pasca Sarjana Universitas Diponegoro, Semarang.

Kusnadi, 2014, Dinas Pertanian dan Ketahanan Pangan Kota Bandung : "Kampung Berkebun Kota Bandung", rilis 17 Juni 2014, http://www.tataruangindonesia.com/fullpost/pertanian/1403019054/ dinas_pertanian_dan_ketahanan_pangan.html, akses tanggal 29 November 2014.

M. Faisal Matenggomena, 2013, Pemanfaatan Sampah Rumah Tangga Untuk Budidaya Tanaman Sayuran Organik di Pekarangan Rumah, SinarTani-Agroinovasi, Badan Litbang Pertanian Jawa Timur,Edisi 17-23 April 2013 Nomor 3503 Tahun XLIII.

Yeti Marleni, Rohidin Mersyah, dan Bieng Brata, 2012, Strategi Pengelolaan Sampah Rumah Tangga di Kelurahan Kota Medan Kecamatan Kota Manna Kabupaten Bengkulu Selatan, Naturalis-Jurnal Penelitian Pengelolaan Sumber Daya Alam dan Lingkungan, Volume 1 Nomor 1 Juni 2012, ISSN 23026715. 
290 | Reni Amaranti, et al.

Improving Nutrition Through Home Gardening, http://www.fao.org/ag/agn/nutrition/household/ garden.stm 